\title{
EXPLORING THE POTENTIAL FOR ENHANCING EXPORT OF AGRICULTURAL PRODUCTS OF LITHUANIAN ORIGIN
}

\begin{abstract}
Purpose - the main purpose of this scientific paper is to reveal the potential of agricultural products of Lithuanian origin to compete in ever-growing international market for Western style food.

Design/methodology/approach -The methods of research employed are as follows: analysis of a scientific literature, analysis of a statistical data, correlation analysis and small sample interview.

Findings - International trade in agricultural products is one of the most competitive sectors of national economy providing a substantial surplus to foreign payments balance. One of potential export facilitators of agricultural products of Lithuanian origin are businessman, engaged in re-export of agricultural products from Lithuania. The ability of Lithuanina agricultural producers to sell their production in the World market is lower than in other similar EU countries.

Research limitations/implications - the research provides insights, on how it could be possible to facilitate export of agricultural products of Lithuanian origin. In order to get clear directions what steps should be taken, there is a need for further researches.

Practical implications - new approach of increasing export of agricultural products of Lithuanian origin is presented.

Originality/Value - The paper provides new insights on Lithuanian international trade in agricultural products.

Keywords: intra-industry trade, export, agricultural products, Lithuania.

Research type: viewpoint.

JEL classification:

F14 - Empirical Studies of Trade

\section{Introduction}

The agricultural sector plays a key role both with respect to its main function, which is to secure food security, and with respect to the non-production functions it serves in the economy and in society. In the coming ten to twenty years greater food consumption is expected to grow in the whole world, particularly in the developing world, where some of the population still do not get the required number of calories per day per capita (UN, 2017) The resulting shifts in consumption patterns from a diet high in starchy foods will have an important impact on global agriculture (Baldos, Hertel, 2014) and on trade of agricultural products. Shifts in the types of foods consumed, from local towards Western style foods (a lot of meat, high glutein, low vegetables, various fermented milk products and etc., food is prepared cooked, not raw), are also expected (Pingali, 2007). It opens new potential markets to countries that produce Western style food products, especially those, which have a surplus of its production. This increase in consumption caused by increasing living standards in developing world and doubled with increasing numbers of population growth shows good
\end{abstract}

${ }^{1} \mathrm{PhD}$, Lithuanian Institute of Agrarian Economics, Lithuania, mangirdas.morkunas@laei.lt 
perspectives for the countries able to deliver Western style food to the World market at comparable prices. Third factor increasing the demand of a Western style food is the result of a globalization process which equilibrates the cultural differences between the world regions and brings Western living style to other parts of the World. In addition to above mentioned, there is another direction of growing demand to agricultural products. The industry demand for particular crops is expected to rise with the growing use of renewable fuels and energy sources in developed world, especially for first generation biofuels which require food crop feedstocks (Fischer et al., 2009). Lithuania, where agricultural sector always played an important role in society and economy (Ferto, Stalgiene, 2016; Kuliesis, Pareigiene, 2016) seeks to benefit from these trends in international food market trying to increase export of its agricultural products. So, the aim of this scientific paper is to analyze the potential of Lithuanian agricultural products to participate in growing international food market.

\section{Theoretical background}

During the last almost two decades from year 1999, to year 2017, trade in agricultural goods in Lithuania passed through a series of structural and institutional changes that influenced its shape and character. The agricultural trade development was influenced especially by the globalization and integration processes that were accelerated by Lithuanian entry into EU. The globalization and internationalization of agrarian trade are closely associated with the development and application of the information and communication infrastructure and technologies, which considerably reduce transaction costs and contribute to the trade in differentiated goods (Svatoš, Smutka, 2012). All these changes not only enhance export of agricultural products from Lithuania, but also speed up collaboration between EU members in all fields. As example of such collaboration can be an intra-industry trade which reveals itself very apparent in trade in agricultural products.

Most of foreign trade in agric-food products of Lithuanian origin can be classified as intra-industry trade between Lithuania and other EU members. The concept of "intra-industry trade" was widely acknowledged in 1975, when a publication by Grubel and Lloyd was revealed. These authors described the character of that trade, differences of it types, proposed methods to measure it as well as the implications for theories on foreign trade and economic policy. The authors proposed a definition to inter-industry trade, rather widely used nowadays: "the value of exports of an "industry" which is exactly matched by the imports of the same industry' (Grubel, Lloyd, 1975, p. 20). Greenway-Hine and Milner (1995) analyzing intra-industry trade added new features to Grubel and Lloyed concept. Distinction between different qualities of a product was called horizontal intra-industry trade and differences in qualities, or services added by the product were called vertical intra-industry trade. Owing to this specific characteristic, intra-industry trade is also referred to as two-way trade, as opposed to one-way (inter-industry) trade. Intra-industry models are basically focused on imperfect competition, arising in FMCG or other goods those consumption mainly depends on the consumer behavior differences in researched countries, that results in an increasing the return to scale and product differentiation (Kawecka-Wyrzykowska et. al., 2017). It can be stated, that from the demand side, the intra-industry trade is driven by diverse consumers' preferences, contrary, from the supply side, the main driver is the increasing returns of scale.

Earlier researches in intra-industry trade were focused in revealing the importance of naturally occurring oligopolies and not very deep product differentiation (Shaked, Sutton, 1984). This view left emerging economies with not very bright perspectives, stating, that lower income country specializing in lower quality products, higher income specializing of quality products, this leading to ever growing gap between developed and emerging world. 
The convergence in the level of GDP between industrial and emerging countries led to an adjustment in this theory. Ekanayake (2001) examining factors influencing Mexican intraindustry trade concludes, that intra-industry trade directly positively correlates with such measures as: nominal GDP per capita, number of countries free trade agreements and the absence of tariffs. This research also concludes that geographical proximity is negatively correlated with intra-industry trade. There are more studies, focused on the influence of trade liberalization on intra-industry trade. In Mardas and Nikas (2008) research on free trade agreements in Southern Balkans it was clearly concluded, that elimination of trade barriers increases intra-industry trade. The same conclusions were drawn by Yoshida et al. (2009) examining the trade between Japan and various European countries. It was also founded that intra-industry trade positively correlates to FDI, and this is especially obvious for new EU member states. It is noteworthy that biggest part of scientific trade theories dealing with intra-industry trade are focused on industrial end-user products, so researches on intra-industry trade in agricultural products are lacking. Because of this reason, based on intra-industry trade parallel with industrial goods and on smooth adjustment hypothesis we can presume, that intra-industry trade is less disruptive to country than inter-industry trade because the adjustment costs take place as a result of any change in the economy such as trade liberalization (Rasekhi, Shodjae, 2012). This aspect of intra-industry trade is important for all countries, but in particular for countries which face more adjustment challenges than the developed countries. In other words, increasing inter-industry trade decreases the adjustment costs (Ruffin, 1999). In addition, as stated in the scientific literature, intraindustry trade helps to "smooth out" the differences in competitiveness (i.e., less competitive countries are more likely to become more competitive) between trading countries and helps to better integrate them into world economy (Kösekahyaoğlu, 2015). This creates another advantage for international trade in agricultural products of Lithuanian origin if we compare it with other products of Lithuanian origin, whose exports usually fall under classification as inter-industry trade.

\section{Research methodology}

Trying to figure out, which agricultural products of Lithuanian origin has the biggest potential to be exported abroad, or which product groups of agricultural products would find its niche in international market more easily than others, we applied statistical analysis of data about Lithuanian export, used correlation analysis between different agricultural product groups of Lithuanian origin and asked a businessman, engaged in international trade of agricultural products to comment on our results and to provide additional insights. The methodology of correlation analysis is presented below.

Let's presume numbers $\mathrm{X}$ and $\mathrm{Y}$ are random numbers and can be defined by covariance equation, which looks as:

$\operatorname{cov}(\mathrm{X}, \mathrm{Y})=\mathrm{E}(\mathrm{XY}-\mathrm{YEX}-\mathrm{XEY}+(\mathrm{EX})(\mathrm{EY}))=\mathrm{E}(\mathrm{XY})-(\mathrm{EX})(\mathrm{EY})$.

And covariance matrix displays common change of random variables $X$ and $Y$ :

$$
V=\left(\begin{array}{cc}
D X & \operatorname{cov}(X, Y) \\
\operatorname{cov}(X, Y) & D Y
\end{array}\right)
$$

When the correliation between variables $\mathrm{X}$ and $\mathrm{Y}$ can be calculated.

Correlation coefficient between two independent variables $\mathrm{X}$ and $\mathrm{Y}$ can be measured in the interval -1 to +1 , or from 0 to +1 . Correlation coefficient value indicates correlation strength.

Correlation matrix can be defined as: 


$$
R=\left(\begin{array}{cc}
1 & \rho(X, Y) \\
\rho(X, Y) & 1
\end{array}\right)
$$

There are many different correlation coefficients. The choice of suitable one depends on the analysis of the variables in the distribution, the estimated forms of dependency and etc. In this research, taking into the account the type of a data, Pearson's pair correlation coefficient was chosen. Two variables $X$ and $Y$ can strongly correlate for three reasons: the variable $X$ affects the variable $Y$; the variable $Y$ affects the variable $X$; both variables $X$ and $Y$ are exposed to the third variable influence. Therefore, the relationship established during the correlation analysis cannot be interpreted as causation, but only as a measure of association or dependency. The Pearson correlation coefficient can be used when the observed random values of $\mathrm{X}$ and $\mathrm{Y}$ are measured on intervals or ratios, and their two-dimensional distribution is normal. The Pearson correlation coefficient of the population (Pearson correlation coefficient) is calculated using the formula:

$$
\hat{\rho}=\mathbf{r}=\frac{\overline{\mathbf{x y}}-\overline{\mathbf{x}} \cdot \overline{\mathbf{y}}}{\sqrt{\overline{\mathbf{x}^{2}}-(\overline{\mathbf{x}})^{2}} \sqrt{\overline{\mathbf{y}^{2}}-(\overline{\mathbf{y}})^{2}}} .
$$

The linear connection is the stronger the $|r|$ the value will be closer to 1 . If $r>0$, then with increasing values for one random variable, the other values increase linearly. If $r<0$, with increasing values for one random variable, the other values decrease linearly. If $r=0$, then there is no linear dependency, but there may be a non-linear dependency. The larger the sample, the correlation coefficient $r$ of the sample is closer to the unknown population correlation coefficient p. Statistically significant value of Pearson's correlation coefficient is from $|0,2|$ to $|0,5|$ (Table 1), but typically we expect statistical significance to be higher than $|0,7|$ in order to be classified as strong and significant.

Table 1. The values of correlation coefficient

\begin{tabular}{|c|c|c|c|c|c|c|c|c|c|c|}
\hline $\begin{array}{c}\text { Very } \\
\text { strong }\end{array}$ & Strong & Medium & Weak & $\begin{array}{c}\text { Very } \\
\text { weak }\end{array}$ & $\begin{array}{c}\text { No } \\
\text { correlation }\end{array}$ & $\begin{array}{c}\text { Very } \\
\text { weak }\end{array}$ & Weak & Medium & Strong & $\begin{array}{c}\text { Very } \\
\text { strong }\end{array}$ \\
\hline-1 & From & from & from & from & & from & from & from & from & \\
& -1 & $-0,7$ & $-0,5$ & $-0,2$ & 0 & 0 & 0,2 & 0,5 & 0,7 & 1 \\
to $-0,7$ & to $-0,5$ & to $-0,2$ & to 0 & & to 0,2 & to 0,5 & to 0,7 & to 1 & \\
\hline
\end{tabular}

Sometimes, additional formula is used for calculation of Pearson correlation coefficient:

$$
\rho_{x y}=\frac{\operatorname{cov}(X, Y)}{\sigma_{X} \sigma_{Y}}=\frac{E\left(\left(X-\mu_{X}\right)\left(Y-\mu_{Y}\right)\right)}{\sigma_{X} \sigma_{Y}} .
$$

This represents the formula presented above, but includes a covariance coefficient. In addition to correlation analysis, a semi-structured interview with businessman involved in international trade of agricultural products was conducted. This research can be treated as supplementary, aimed at clarifying agricultural product groups of Lithuanian origin, which may have the biggest potential for export and to reveal the reasons, why Lithuanian businessman engaged in foreign trade of agricultural products are reluctant to trade in 
agricultural products of Lithuanian origin. There were 5 interviewers from Panevėžys and Vilnius districts.

\section{Research results and findings}

Trade in agricultural products is highly demonopolised and markets for some of these products can be considered very close to perfectly competitive markets (in particular wheat and cocoa future exchanges). However, there are various scientific views. Although the production sectors of agricultral goods are usually assumed to be almost perfectly competitive, regardless the kind of an agricultural product (cattle, grain, fruits, vegetables, etc.), some of them show the monopolistically competitive features, noticeable in various some sectors, especially in the sector of final good production, that are mostly ignored. A few studies like Soukup at al. (2014), Anwar (2010) feature the intermediate production sector with monopolistic competition when analyzing the relation between international factor mobility and skilled-unskilled wage gap, but Anwar (2010) neglects to take the monopolistically competitive final-good production into consideration. The market of perfect competition, in which the economic, political power, information asymmetry, and other factors that create power relations in trading transactions are no longer relevant in terms of both the buyer and the seller, is one of the most attractive trading platforms for small market players, as small countries in direct international trade negotiations are often forced to make additional concessions. It is probably that the possibility of obtaining a fair price for the product sold and the abolition of tariff and non-tariff trade restrictions occurred after Lithuania's accession to the EU created incentives for such a significant growth of trade in agricultural products, which during the particular period exceed a countries GDP growth by 6 times (Figure 1).

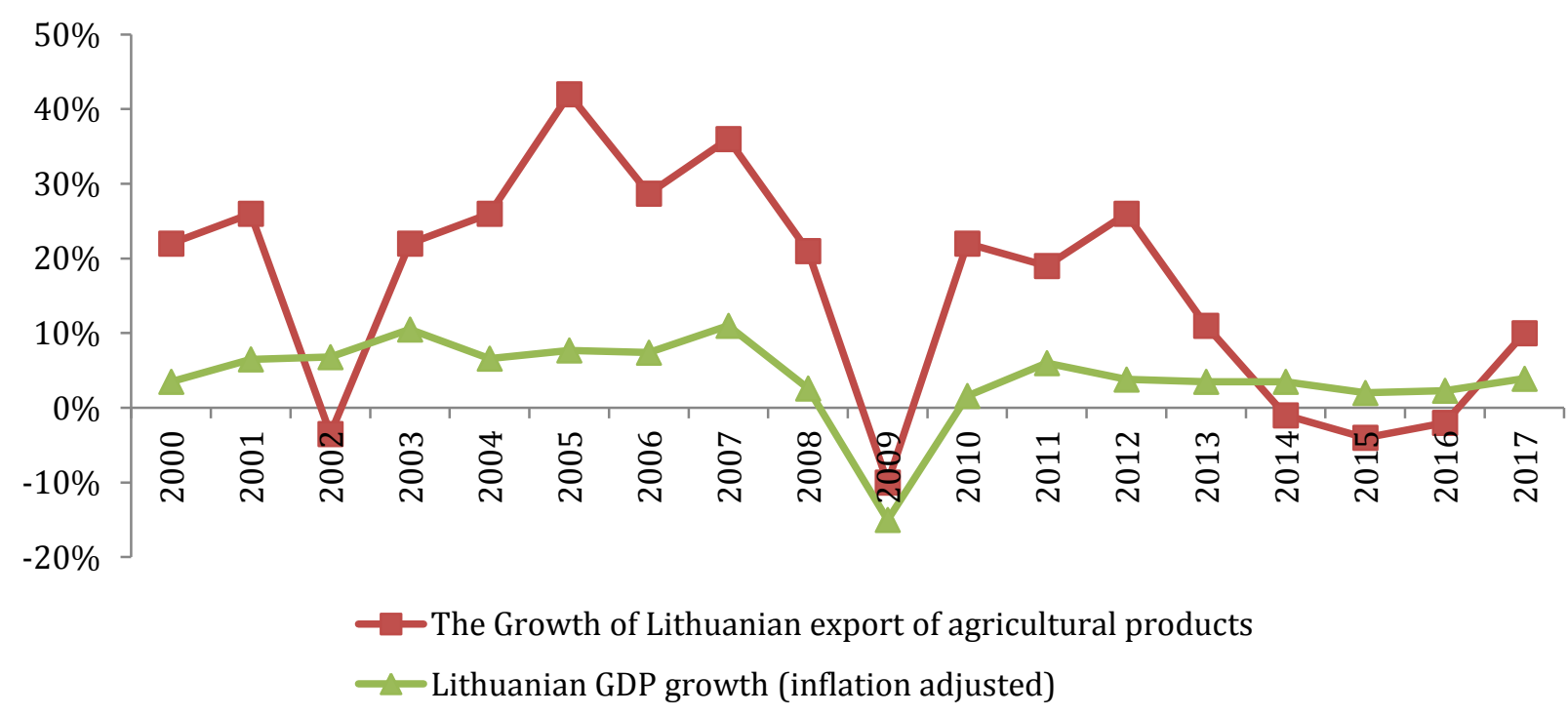

Source: compelled by the author using data from Lithuanian Statistical Office

Figure 1. Comparison of Lithuanian exports of agricultural products and real GDP growth rates

During the financial crisis (2009), the country's export of agricultural products declined significantly less than that of Lithuania's GDP. It can be presumed that the Lithuanian international trade in agricultural products sector is one of the most competitive sectors of the country's economy, the further strengthening of which could be understood as a priority 
of the state, not only improving the balance of the country's foreign trade, but also making the country's economy more resistant to strong external shocks while jobs in this sector are more stable.Meter of GDP, gross domestic product, is one of the most widely used measures of economic growth of the country. GDP shows the actual economic level of the country, and whether it is growing and moving forward or stagnating and slowing down. Changes in the country production levels show halfway where the economy is going and how the market subjects behave because its actions and decisions act as a form of the meter (Milczarek, 2014). Compared an export growth rates to a GDP growth rates we can state, that after accesion to EU, the export of agricultral products acted as one of a whole GDP growth triggers, but after Russian embargo on Lithuanian products, it took almost three years till Lithuanian firms, engaged in foreign trade of agricultural products found substitutes to Russian market. Before Russian embargo, Lithuanina food producers (especially milk products) saw Russian market as a prioritative export market because of its profitability. Some biggest Lithuanina milk products producers (SC „Rokiškio sūris“, SC „Pieno žvaigždès“) treated Russia as it's main trading partner selling more than 50 percent of its production there. Such a dependancy on one not very reliable trading partner in 2014 converted into significant losses after that all Lithuanian agricultral producers diversified their export portfolios allocating no more than 10 percent of export sales to non EU contry. Now it can be stated, what today Lithuanina export of agricultural products is more healthy (Fitzova, Židek, 2015), because now the client portfolio of Lithuanian export of agricultural products is much more diversified and not depending on one client (Russia) as it was before. Such a shift can be also credited in Lithuanina economy achieving sustainability, because lower risks in export markets also lowers the risks of bancruptcies and loosing jobs in Lithuanian agricultural sector.

International trade in agricultral products is one of the most obvious examples of the benefits Lithuania gained after accession to the EU. Already in 2004, the export of agricultural products almost equaled its imports, although in this year Lithuania enjoyed the benefits of the EU single market for only 2/3 years. It is obvious that this is not in any way connected with any sudden significant increase in agricultural production in the country. Both dairy and meat production, as well as other players in the food production industry need a time frame in which, in response to new incentives (direct payments to farmers, EU support for farm modernization, the opening of 500 million consumers' market, etc.) agricultral producers would increase their capacities and the quantities of final products produced. Thus, this comparison, and since 2005, the positive foreign trade balance in agricultral products trade should be linked to the ability of Lithuanian entrepreneurs involved in the re-export of agricultural products from third countries to react suddenly to abolishment any of trade restrictions, what were in force before Lithuanian accession to EU. Such activities of Lithuanian business engaged in the re-export of agricultural products from third countries, while benefiting the country in the macro-economic sense in the short term due to the impact on the reduction of the trade deficit, simultaneously create some pressure and competition for the producers of agricultral products of the country, as Lithuanian agricultural producers are compelled to compete with third country producers, both on foreign markets and for the possibility of selling their products internally. These insights are also illustrated by the share agricultral products of Lithuanian origin in the overall structure of Lithuanian exports of agricultural products. It dropped from 90.4 percent in 1999 to 64 percent in 2013, what is not satisfactory; by 2017 this proportion has risen to 73.7 percent. Such a significant difference is that, in a given year, even one third of the agricultural output exported from Lithuania is produced in another country, showing a number of negative aspects observed in the Lithuanian agricultural sector. First of all, it can be noted that world demand for agricultral products is steadily increasing; Lithuanian businessmen who are engaged in international 
trade in agricultural products are able to compete on the world market and sell even more agricultural products than Lithuania is able to produce. This shows a very good prospect for the Lithuanian agricultural sector to take advantage of the Lithuanian entrepreneurs' ability to sell agricultral products, even though they have set the goal to achieve a $90 \%$ ratio in 1999 (the assumption is made that achieving a higher ratio is too complicated due to the geographical situation in Lithuania, which determines that some cultures in Lithuania are inappropriate or ineffective in production (eg.: citrus fruit, cocoa, etc.)) between exports of agricultral products of Lithuanian origin and exports of all agricultral products from Lithuania, the country has an additional potential of 820 million EUR of turnover. Analyzing the reasons why Lithuanian agricultural traders are reluctant to share their success with Lithuanian farmers, it can be noticed that they do not receive any additional benefits due to the increase in sales of agricultral products of Lithuanian origin at the expense of agricultural production from other countries.

One of the motives for Lithuanian business entities to increase the share of Lithuanian agricultral products in the total portfolio of their products could be the benefits provided by the horizontal integration for all actors in the supply chain (the initial beginnings of such a scenario can already be observed in Lithuanian agriculture, for example, Linas Agro Group). It is likely that some corrections in implementation of the common agricultural policy in the country could also be significant here. It is presumable, that the easiest way to achieve this synergistic effect - the bigger growth in export of agricultral products of Lithuanian origin is in following agricultural product groups: products of animal origin, which do not fall into other categories (05), edible vegetables and its products (07), sugar and its products (17), prepared feed for animals (23). It is noteworthy that the increase in exports of these agricultural product groups of Lithuanian origin would not be very complicated also because of the very strong positive correlation between exports of these Lithuanian agricultural products. It is not surprising, because these product groups complement each other in production chains, or represent a waste of some production processes of each other (ex. waste, which occurs in preparing vegetable products, is used in preparing feed for animals; products of animal origin (not used in other production processes parts of cattle or pigs) are also used in feeding other animals (making food for cats and dogs).

\section{Table 2. Correlation coefficients in selected groups of products of Lithuanian agricultural exports}

\begin{tabular}{|c|c|c|c|c|}
\hline Product group/ Correlation coefficient & $\begin{array}{c}\text { Products of } \\
\text { animal origin } \\
(05)\end{array}$ & $\begin{array}{c}\text { Edible } \\
\text { vegetables and } \\
\text { its products } \\
\text { (07) }\end{array}$ & $\begin{array}{c}\text { Sugar and its } \\
\text { products } \\
\text { (17) }\end{array}$ & $\begin{array}{c}\text { Prepared feed } \\
\text { for animals } \\
(23)\end{array}$ \\
\hline Products of animal origin (05) & 1 & 0,847 & 0,89 & 0,577 \\
\hline Edible vegetables and its products (07) & 0,847 & 1 & 0,846 & 0,863 \\
\hline Sugar and its products (17) & 0,89 & 0,846 & 1 & 0,868 \\
\hline Prepared feed for animals (23) & 0,577 & 0,846 & 0,868 & 1 \\
\hline
\end{tabular}

Source: compelled by the author

As can be seen from the table above, the Pearson correlation coefficient between 05 and 07 product groups is 0.847 (which means a very strong correlation and is described by $84.7 \%$. of data sequence), Between 05 and 17 agricultural product groups Spearmen correlation coefficient is even higher - it is equal to 0.89. Correspondingly, the coefficients determining the high, positive significant interdependence are also observed among other groups of agricultural products of Lithuanian origin. 
Based on the results of statistical correlation analysis, as well as on interviews with exporters of agricultural products data, it could be stated that increased exports of one category of agricultural products of Lithuanian origin would facilitate international trade in other agricultural products of Lithuanian origin, because of increasing awareness and positive customer experience (due to high the quality of agricultural products of Lithuanian origin) increases interest in them and facilitates sales operations.

The second factor, which does not encourage Lithuanian businessmen, involved in international trade in agricultural products, to expand the export of agricultural products of Lithuanian origin - its price. Part of the crops grown in the country, because of objective reasons (vegetative period, sunny hours in vegetative period, etc.) cannot compete with imported or re-exported agricultural products. This is precisely why there is a large trade deficit with Spain in trade in agricultural products (-133.3 million in 2017), France (-67 million euros) and other countries of warm climate zones. It is interesting that the largest deficit in Lithuanian trade in agricultural products is with countries that are close or even more severe than Lithuania in their climatic conditions and have higher average wages, higher energy prices, such as Poland (-177 million), the Netherlands (- EUR 168 million), Sweden (105 million EUR). Taking into account above mentioned international trade theories, it can be stated that the above-mentioned data testify to the ineffectiveness of Lithuanian agriculture, and the concentration on cultures that are not as in demand as crops grown in other EU countries, which have poorer conditions (for example, in Poland the amount of EU support for farmers corresponds to the amount of support for Lithuanian farmers, the climatic conditions are similar, wages and energy costs are higher) than Lithuanian farmers. Scientific literature imposes what the intra-industry trade promotes innovations. Producing a greater variety and number of goods increases the general knowledge about technology, and a greater knowledge implies smaller costs of the knowledge accumulation (Rasekhi, Shjodae, 2012), which can help use the "know-how" of one crop to grow other crops, but bearing in mind that the current situation with remuneration for the production of agricultural products is to a large extent satisfying to Lithuanian farmers (which is indicated by the increasing concentration in the agricultural sector, the augmentation of farms and profitability), it is hard to expect, that Lithuanian producers of agricultural products would start changing its product portfolio structure or start investing in the use of new information and communication technologies and extrapolation of created "know-how" into economic benefits. This requires external stimuli, as one of them could be changes in the overall policy of supporting agriculture in the country. The state, which is not satisfied with trade deficit in certain types of agricultural products and in relevantly small share of agricultural products of Lithuanian origin in all export of agricultural products from Lithuania, should take substantive steps that can substantially adjust the existing structure of the market for agricultural products.

Analyzing Lithuanian intra-industry trade with other EU members we notice a big deviation from a traditional scientific literature, focusing on international trade. According to Ambroziak (2017) intra-industry trade flourishes only in contries, comparable in size, level of economic development, level of FDI in respected contries and those geographical proximity is not very high. Only one Lithuanian trading partner in agricultural products meets above mentioned criteria - Estonia. All Other emphisize all the factors, that, according scientific literature, should impede intra-industry trade: Spain and France are much larger, more economically develeoped countries with higher levels of FDI, The Netherlands and Sweden have much higher GDP per capita levels, Poland's economy is much bigger in size. It cannot be stated, that our findings neglect or diminish the importance of scientific literature. We conclude, that Lithuanian business entities, that export their products to EU, may be focusing on their traditional trade partners, not searching for new opportunities, so these insights may 
sugest to Lithuanian exporters look for partners in countries, comparable to Lithuania according above mentioned criteria. It could be a niche, helping to increase a percentage of agricultural products of Lithuanian origin witih the whole export of agricultural products from Lithuania.

\section{Conclusions}

Agricultural product market shows signs of a perfect competition market, which is very atractive to small countries, able to provide products what meets changing worlds consumer preferences, because in worldwide future exchage markets even small seller can expect to recieve fair price for their products. It is absolutely opposite to billateral international trade agreements, where smaller weaker market players (states) must provide substantial concessions.

International trade in agricultural products is one of the most competitive sectors of national economy providing a substantial surplus to foreign payments balance, speeding up economic development and providing country with work places, that are more stable than average, compared to other sectors of national economy.

One of potential export facilitators of agricultural products of Lithuanian origin are businessman, engaged in re-export of agricultural products from Lithuania. Government should make adjustments in common agricultural policy in order to encourage businessman, engaged in international trade of agricultural products to enhance their product portfolio with more products of Lithuanina origin.

The producers of Lithuanian agricultural products are not able to sell their products into World market at the equal terms as other EU member states agricultural producers, but the ability of lithuanian businessman, engaged in international trade in agricultural products seem as favourable condition in Lithuanina ability to take advantage in growing international demand of Western style food products.

\section{References}

1. Ambroziak, L. (2017) Decomposition of Poland's Bilateral Trade Imbalances by Value Added Content. Entrepreneurial Business and Economics Review, Vol. 5, Iss. 2, pp. 51-69

2. Anwar, S. (2010) Wage Inequality, Increased Competition, and Trade Liberalization: Short Run vs Long Run. Review of International Economics. Vol. 18, Iss. 3, pp. 574-581

3. Baldos, U., L., C., Hertel, T., W. (2014) Global food security in 2050: the role of agricultural productivity and climate change. The Australian Journal of Agricultural and Resource Economics. Vol. 58, Iss. 4.pp. 554-570

4. Ekanayake, E., M. (2001) Determininats Of Trade: The Case Of Mexico. The International Trade Journal, Vol. 15, Iss. 1, pp. 89-112

5. Ferto, I., Stalgienė, A. (2016) Effects of agricultural subsidies on income risk in Lithuanian dairy farms. Management Theory and Studies for Rural Business and Infrastructure Development, Vol. 38, No. 4, pp: 351358. DOI: DOI: https://doi.org/10.15544/mts.2016.27

6. Fischer, G., Hizsnyik, E., Prieler, S., Shah, M. and van Velthuizen, H. (2009). Biofuels and Food Security: Implications of an Accelerated Biofuels Production. Organization of the Petroleum Exporting Countries Fund for International Development, Vienna, Austria.

7. Fitzová, H., Žídek, L. (2015) Impact of Trade on Economic Growth in the Czech and Slovak Republics, Economics and Sociology, Vol. 8, No 2, pp. 36-50. DOI: 10.14254/2071-789X.2015/82/4

8. Grubel, H. G., Lloyd, P. J. (1975) Intra-industry trade: the theory and measurement of intra-industry trade in differentiated products. Macmillan, London, $205 \mathrm{p}$.

9. Kawecka-Wyrzykowska, E., Ambroziak, Ł., Molendowski, E., Polan, W. (2017). Intra-Industry Trade of the New EU Member States: Theory and Empirical Evidence. Warszawa: PWN, 168 p. 
10. Kösekahyaoğlu, L. (2015) Does Trade Liberalisation Matter?: An Analysis of Intra-Industry Trade for Turkey and the EU. Marmara Üniversitesi Avrupa Topluluğu Enstitüsü Avrupa Araştırmaları Dergisi, Vol. 10, Iss. 1, 113-135.

11. Kuliesis, G., Pareigiene, L., (2016) Evaluation of the eu support for rural residents of Lithuania: rural elders approach. Management Theory and Studies for Rural Business and Infrastructure Development, Vol. 38, No. 4, pp: 384-393. DOI: https://doi.org/10.15544/mts.2016.30

12. Mardas, D., Nikas, C. (2008) European Integration, Intra-industry Trade in Vertically Differentiated Products and the Balkan Countries. International Advances in Economic Research. Vol. 14, Iss. 4, pp. $355-368$

13. Milczarek, A. (2014) Africa as a new potential of the global economy, Journal of International Studies, Vol. 7, No 2, pp. 152-160. DOI: 10.14254/2071-8330.2014/7-2/1

14. Pingali, P. (2007) Westernization of Asian diets and the transformation of food systems: Implications for research and policy. Food Policy, Vol. 32, Iss.3, pp: 281-298

15. Rasekhi, S., Shodjae, S., S. (2012) Determinant factors of the vertical intra-industry trade in agricultural sector: A study of Iran and its main trading partners. Agricultural Economics, Vol. 58, Iss. 4, pp. 180190

16. Ruffin, R. (1999) The Nature and Significance of Intra-Industry Trade. Economic and Financial Review, (4): pp.1-8.

17. Shaked, A., Sutton, J. (1984) Involuntary Unemployment as a Perfect Equilibrium in a Bargaining Model. Econometrica, Vol. 52, No. 6, pp. 1351-1364

18. Soukup, A., Brčák, J., Svoboda, R. (2014) Monopolistic Competition in the International Trade of Agricultural Products. Agris on-line Papers in Economics and Informatics. Vol. 6, No. 1, pp. 87-97

19. Svatoš, M., Smutka, L. (2012) Development of agricultural trade and competitiveness of the commodity structures of individual countries of the Visegrad Group. Agricultural Economics/Zemedelska Ekonomika, Vol. 58, Iss. 5, pp: 222-238

20. United Nations press report (2017) Warning of dire food shortages in Horn of Africa, UN agriculture agency calls for urgent action. [accessed 201806 08] available at the Internet: https://news.un.org/en/story/2017/01/550422-warning-dire-food-shortages-horn-africa-un-agricultureagency-calls-urgent

21. Yoshida, Y., Leitao, N., C., Faustino, H., C. (2009) Vertical Intra-Industry Trade and Foreign Direct Investment between Japan and European Countries. Atlantic Economic Journal, Vol. 37. https://doi.org/10.1007/s11293-009-9192-8 